\title{
Dietary lysine requirement of juvenile Silver pompano, Trachinotus blochii (Lacepede, 1801)
}

\author{
Sanal Ebeneezar, ${ }^{\mathrm{a}, *}$, P. Vijayagopal ${ }^{\mathrm{a}}$, P.P. Srivastava ${ }^{\mathrm{b}}$, Subodh Gupta $^{\mathrm{b}}$, Sikendrakumar ${ }^{\mathrm{b}}$, \\ Tincy Varghese ${ }^{\mathrm{b}}$, D. Linga Prabu ${ }^{\mathrm{a}}$, S. Chandrasekar ${ }^{\mathrm{a}}$, Eldho Varghese ${ }^{\mathrm{a}}$, P. Sayooj ${ }^{\mathrm{a}}$, C.S. Tejpal ${ }^{\mathrm{c}}$, \\ Livi Wilson ${ }^{\mathrm{a}}$ \\ ${ }^{a}$ Central Marine Fisheries Research Institute, Kochi 682 018, Kerala, India \\ ${ }^{\mathrm{b}}$ Central Institute of Fisheries Education, Mumbai 400061, India \\ ${ }^{\mathrm{c}}$ Central Institute of Fisheries Technology, Kochi 682003, India
}

\section{A R T I C L E I N F O}

\section{Keywords:}

Juvenile pompano (Trachinotus blochii)

Lysine

Growth, serum biochemistry

\begin{abstract}
A B S T R A C T
A 12-week feeding trial was conducted to quantify the dietary lysine requirement of juvenile silver pompano with an initial average weight of $6.28 \mathrm{~g}$ reared in indoor recirculatory system. Six treatment diets were designed with isonitrogenous, isolipidic and isoenergetic diets. (42\% CP, 6\% CL and $4.28 \mathrm{kcal} \mathrm{g}^{-1} \mathrm{GE}$ ) were formulated with graded levels of lysine (1.52, 1.85, 2.21, 2.49, 2.74 and 2.98 g/100 g, dry diet). Equal amino acid nitrogen was maintained by replacing lysine with nonessential amino acid mixture. Fish were randomly stocked, in triplicate groups, in $180 \mathrm{~L}$ indoor glass rectangular tanks with recirculatory system and fed to apparent satiation over two feedings at 10:00 and 16:00 h daily during the experimental period. The results indicated that there were significant differences in growth and feed utilization among the treatments. Fish fed diets with lysine in different treatments showed high survival rate (95-100\%). Maximum weight gain (WG), specific growth rate (SGR) and protein efficiency ratio (PER) occurred at $2.21 \%$ dietary lysine. The hepatosomatic index (HSI), viscerosomatic index (VSI) and crude protein content in whole body were significantly affected by dietary lysine levels. There were significant differences $(P<.05)$ in total serum protein levels and erythrocyte count in fish fed diets with different dietary lysine levels. No significant differences were observed in the levels of serum glucose, triglycerides and creatinine levels among the treatments. In the present study, optimization of fitted quadratic regression of weight gain\%, SGR, PER and FER on lysine in diet revealed that the optimum lysine requirement of silver pompano was in the range of $2.40-2.45 \%$ of dry diet $(5.71-5.83 \%$ of dietary crude protein).

Statement of relevance: First report of lysine requirement of juvenile silver pompano.
\end{abstract}

\section{Introduction}

Development of well-balanced and complete species specific formulated feed is one of the major steps which determines the success of aquaculture operations. At the same time, the inclusion level of expensive ingredients should be well-optimized as per the requirements. However, the feed should be complete and balanced in order to satisfy the nutritional requirement of the cultured species. Lack of adequate information regarding nutritional requirements is a major contributing factor towards poor growth and efficiency in fish (Watanabe, 1995; Heilman and Spieler, 1999). Optimization of dietary protein levels along with increasing nutrient retention by the fish could reduce nitrogen loading and positively influence production costs (Thoman et al., 1999). Apart from gross dietary protein, optimum amino acid profile is also inevitable for enhancing the growth and production of fish.

Fish require the same ten essential amino acids in their diet as other animals for maximum growth (NRC, 2011). The deficiency of indispensable amino acids will result in reduced growth performance and feed utilization (Wilson and Halver, 1986). Therefore, it is important to satisfy the indispensable amino acid requirements of fish in addition to balancing the protein in fish feeds.

Lysine is generally the most limiting essential amino acid in the plant based ingredients especially cereals used for fish feeds (Forster

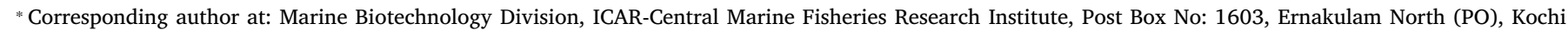
682018, Kerala, India.

E-mail address: sanalebeneezar@gmail.com (S. Ebeneezar). 
and Ogata, 1998; Small and Soares Jr, 2000; Mai et al., 2006; Gatlin et al., 2007) and is found in the highest concentration in the carcass of most of the fish species (Wilson and Poe, 1985; NRC, 1993). Due to the elevated use of plant protein sources, deficient amino acids are commonly supplemented in fish diets (Fournier et al., 2003; NRC, 2011). Supplementation with a single or a mixture of amino acids may enhance protein synthesis and muscle growth in farm animals (Wu et al., 2009).

Dietary lysine supplementation may result in increased weight gain (Khan and Abidi, 2011; Yang et al., 2011), nitrogen retention (Cao et al., 2012) and reduction in body fat content of fish (Berge et al., 1998; Nguyen et al., 2013). Lysine serves as the precursor of carnitine which acts as a carrier of long chain fatty acids into the mitochondria for $\beta$-oxidation (Walton et al., 1984), thus taking part in lipid metabolism. In addition, lysine participates in a single metabolic pathway targeted for muscle growth (Valente et al., 2013).

Deficiency of dietary lysine results in loss of appetite, growth retardation, fin erosion and increased mortality in fish (Borlongan and Benitez, 1990; Mai et al., 2006; Ketola, 1983). Researchers had reported the lysine requirements of commonly cultured fish species in the range from 3.2 to $6.2 \%$ dietary protein (Ogino, 1980; Robinson et al., 1980; Akiyama et al., 1985; Arai and Ogata, 1991; Griffin et al., 1992; Gurrea et al., 2001; Tantikitti and Chimsung, 2001; Wilson, 2002).

The silver pompano, also known as Snubnose pompano or American pomfret is a pelagic marine fish species (Order: Perciformes, Family: Carangidae), distributed mainly in the Indo-Pacific region (Kapoor et al., 2002). It is one of the top most preferred high value species for mariculture due to its faster growth rate, good meat quality and high market demand. The broodstock development and seed production technology of this species had been recently standardized by the Central Marine Fisheries Research Institute, Kochi, India and seeds are supplied on a large scale to entrepreneurs (Gopakumar et al., 2012). The culture of this species is widely picking up in several parts of India, in cages as well as in near shore ponds using low cost fish and pelleted feeds as the major diet. At present, a nutritionally balanced formulated feed is not available for silver pompano, which present an obstacle for commercial production. The development of a cost effective formulated feed is in progress. One of the prerequisites for developing high efficiency diet for any fish species is the complete knowledge of its amino acid requirements, in order to elaborate balanced and sustainable aquafeeds to avoid deficiency or excess of amino acids which can promote imbalance or antagonisms and impaired effects on growth performance and health of fish (Li et al., 2009). To our knowledge, no information has been published concerning the lysine requirements of this species. Therefore, this investigation was undertaken to determine the dietary lysine requirement for juvenile silver pompano.

\section{Material and methods}

\subsection{Diet preparation}

Six isonitrogenous and isolipidic (42\% CP, 6\% CL) amino acid test diets were formulated using casein, gelatin and L-crystalline amino acids with graded levels of L-lysine (Table 1). The dietary protein level was fixed at $42 \% \mathrm{CP}$, based on our previous work which reported satisfactory for the optimum growth of T. blochii (Unpublished data). Essential amino acids were added to simulate the whole body amino acid composition of juvenile silver pompano (with $6.28 \mathrm{~g}$ mean body weight) except for lysine. The levels of L-lysine were in increments of $0.3 \mathrm{~g} / 100 \mathrm{~g}$ in different feeds. A casein-gelatin ratio (4:1), contributing the minimum quantity of the test amino acid and maximum quantities of other amino acids was maintained. To make the diets isonitrogenous, lysine was quantitatively increased at the expense of the non-essential amino acid, glycine.

Preweighed quantities of L-crystalline amino acids were thoroughly stirred in hot water $\left(80^{\circ} \mathrm{C}\right)$ and the $\mathrm{pH}$ of the resulting mixture was adjusted to neutral with $6 \mathrm{~N} \mathrm{NaOH}$ solution (Nose et al., 1974). The
Table 1

Ingredient composition of experimental diets.

\begin{tabular}{|c|c|c|c|c|c|c|}
\hline \multicolumn{7}{|l|}{ Diets } \\
\hline & D1 & D2 & D3 & D4 & D5 & D6 \\
\hline \multicolumn{7}{|c|}{ Ingredients ( $\mathrm{g} / 100 \mathrm{~g}$ dry weight) } \\
\hline Casein $^{\mathrm{a}}$ & 24.0 & 24.0 & 24.0 & 24.0 & 24.0 & 24.0 \\
\hline Gelatin $^{\mathrm{b}}$ & 6.0 & 6.0 & 6.0 & 6.0 & 6.0 & 6.0 \\
\hline Dextrin White & 20.1 & 20.1 & 20.1 & 20.1 & 20.1 & 20.1 \\
\hline Carboxy methyl cellulose & 1.5 & 1.5 & 1.5 & 1.5 & 1.5 & 1.5 \\
\hline Cellulose powder & 10.0 & 10.0 & 10.0 & 10.0 & 10.0 & 10.0 \\
\hline Starch soluble & 10.0 & 10.0 & 10.0 & 10.0 & 10.0 & 10.0 \\
\hline Fish oil & 4.0 & 4.0 & 4.0 & 4.0 & 4.0 & 4.0 \\
\hline Sunflower oil & 2.0 & 2.0 & 2.0 & 2.0 & 2.0 & 2.0 \\
\hline Vitamin-mineral $\mathrm{mix}^{\mathrm{c}}$ & 2.0 & 2.0 & 2.0 & 2.0 & 2.0 & 2.0 \\
\hline Vitamin $\mathrm{C}^{\mathrm{d}}$ & 2.0 & 2.0 & 2.0 & 2.0 & 2.0 & 2.0 \\
\hline Essential AA mix ${ }^{\mathrm{e}}$ & 6.5 & 6.5 & 6.5 & 6.5 & 6.5 & 6.5 \\
\hline Lysine & 0 & 0.3 & 0.6 & 0.9 & 1.2 & 1.5 \\
\hline NEAA mix ${ }^{f}$ & 11.4 & 11.1 & 10.8 & 10.5 & 10.2 & 9.9 \\
\hline Glycine & 6.4 & 6.1 & 5.8 & 5.5 & 5.2 & 4.9 \\
\hline Choline Chloride & 0.5 & 0.5 & 0.5 & 0.5 & 0.5 & 0.5 \\
\hline \multicolumn{7}{|l|}{ Proximate composition (\%) } \\
\hline Crude protein & 42.23 & 42.33 & 42.27 & 41.91 & 42.23 & 42.25 \\
\hline Crude lipid & 6.22 & 6.43 & 6.19 & 6.31 & 6.33 & 6.24 \\
\hline Total lysine & 1.58 & 1.88 & 2.18 & 2.48 & 2.78 & 3.08 \\
\hline Analysed lysine & 1.52 & 1.85 & 2.21 & 2.49 & 2.74 & 2.98 \\
\hline
\end{tabular}

a Crude protein (85\%), Himedia, India.

b Crude protein (93\%), Himedia, India.

c Vitamin-mineral mixture (Supplevite ${ }^{\circledast}$ ): composition per $250 \mathrm{~g}$ : vit. A$500000 \mathrm{IU}$, vit. D3-100,000 IU, vit. B2-200 mg, vit. E- 75 units, vit. K- $100 \mathrm{mg}$, Ca pantothenate- $250 \mathrm{mg}$, Nicotinamide- $100 \mathrm{mg}$, vit. B12-600 mg, choline chloride- 15,000 mg, Ca- 75,000 mg, Mn- 27,500 mg, I- 100 mg, Fe- 750 mg, Zn$1500 \mathrm{mg}$, Cu- $200 \mathrm{mg}$, Co- $45 \mathrm{mg}$.

${ }^{\mathrm{d}}$ Vitamin C (STAY-C): DSM Nutritional Technologies, Mumbai, India.

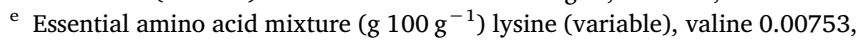
isoleucine 0.51506 , leucine 0.50 , threonine 0.89652 , tryptophan 0.8214 , phenylalanine 0.82142 , methionine 1.12587 , arginine 0.82724 , histidine 0.93686 , (Himedia, India)

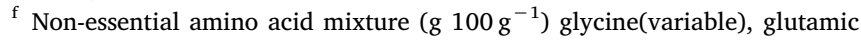
acid 1.0, Alanine 1.0, proline 0.25 , cystine 0.75 , aspartic acid 1.0 , tyrosine 1.0 , (Himedia, India).

required amount of gelatin was dissolved separately in water with constant heating and stirring and then transferred to the amino acid mixture according to Abidi and Khan (2007). The rest of the dry ingredients and oil premix were mixed thoroughly along with the amino acid and gelatin solution to form a dough. The dough was passed through a pelletizer fitted with a 2 -mm die to obtain pellets which were dried in hot air oven at $45^{\circ} \mathrm{C}$ for $24 \mathrm{~h}$ to reduce the moisture content below $10 \%$. The dry pellets were crumbled, sieved and stored at $4{ }^{\circ} \mathrm{C}$ until fed.

\subsection{Fish, experimental design and conditions}

Juveniles of silver pompano ( $T$. blochii) were obtained from the Marine fish hatchery of ICAR-Central Marine Fisheries Research Institute (ICAR-CMFRI), Mandapam, Tamil Nadu, India. The fishes were transported to the wet laboratory of ICAR-CMFRI, Kochi, India, in oxygen-filled polythene bags, given a prophylactic dip in $\mathrm{KMnO}_{4}$ solution (1:3000) and stocked in indoor fibre reinforced plastic (FRP) tanks (water volume, $1000 \mathrm{~L}$ ) for 15 days. During this period, fish were fed to satiation using a practical feed (CP $42 \%$ and CL 6\%), twice daily, at 10:00 and 16:00 h. Later, these fishes were acclimated for 2 weeks on casein-gelatin based diet ( $42 \% \mathrm{CP})$.

At the beginning of the experiment, fish (average initial weight and length about $6.28 \mathrm{~g}$ and $5.76 \mathrm{~cm}$, respectively) with the same size were weighed, measured for body length and randomly stocked into eighteen $180 \mathrm{~L}$ rectangular glass tanks with 8 fish for each replicate. Triplicate groups of fish were used for testing each diet. Feed was not offered to 
fish on the day of sampling. Initial and weekly weights were recorded on a top-loading balance (Hercules HT SS V4) and feed allowances adjusted accordingly. They were provided with a continuous flow of filtered seawater with continuous aeration to maintain the dissolved oxygen level above saturation. The temperature of ambient water was maintained at $27^{\circ} \mathrm{C}$ using a $1000 \mathrm{~W}$ thermostat (AquaZonic, China). Fish were fed by hand to apparent satiation twice daily at 1000 and $1600 \mathrm{~h}$. The faecal matter and unconsumed feed were siphoned out daily, and the feeding trial lasted for 12 weeks. From weeks 1 to 4 , $1.5 \mathrm{~mm}$ pellets were fed, thereafter, $2 \mathrm{~mm}$ pellets were fed until the end of the experiment. Water quality parameters were monitored daily between 0900 and $1500 \mathrm{~h}$. Dissolved oxygen and ammonia were measured using commercial water quality testing kits (Nice chemicals (P) Ltd. India) and $\mathrm{pH}$ using an electronic $\mathrm{pH}$ meter (Cyberscan 5500, Eutech instruments, Singapore). During the experimental period, salinity was $17-20 \%$, $\mathrm{pH}$ was 7.6-7.8, ammonia nitrogen was $<0.05 \mathrm{mg}$ / $\mathrm{L}$, and dissolved oxygen was $5-6 \mathrm{mg} / \mathrm{L}$.

\subsection{Samples collection}

In the beginning of the experiment, twenty fish were sampled for the analysis of proximate whole body composition. After termination of the 12-week feeding trial, fish in each tank were individually weighed. Six fish from each tank were used for the analyses of proximate composition. The livers and viscera were dissected from fish and weighed for the calculation of hepatosomatic index (HSI) and viscerosomatic index (VSI), respectively. Feed was not offered to fish on the day of sampling. Blood samples were drawn from the caudal vein of 6 fish from each treatment and used to determine blood characteristics according to the method described by Kikuchi et al. (1994). Serum was prepared and stored at $-20^{\circ} \mathrm{C}$ for further analysis.

\subsection{Growth and nutrient utilization parameters}

Weight gain (WG, \%) and Specific growth rate (SGR) were used as indicators for growth performance. Feed conversion ratio (FCR) and protein efficiency ratio (PER) were used as indicators for feed utilization. The relative weights of liver, viscera and intraperitoneal fat are expressed in terms of hepatosomatic index (HSI), viscerosomatic index (VSI) and intraperitoneal fat ratio (IPFR, \%), respectively.

The variables were calculated as follows:

(i) WG (\%) $=100 \times$ (final body weight - initial body weight $) /$ initial body weight

(ii) SGR $(\%)=100 \times($ ln final weight $-\ln$ initial weight $) /$ days of the experiment

(iii) FCR $=$ feed fed (g, dry weight) / body weight gain (g)

(iv) $\mathrm{PER}=$ body weight gain $(\mathrm{g}) /$ protein intake $(\mathrm{g})$

(v) HSI $(\%)=100 \times$ (liver weight, $g /$ whole body weight, $g$ )

(vi) VSI $(\%)=100 \times($ viscera weight, $g /$ whole body weight, $g$ )

(vii) IPFR $(\%)=100 \times$ (Intra peritoneal fat weight, $g /$ whole body weight, $g$ )

\subsection{Chemical analyses}

Crude protein, crude lipid, moisture and ash in diets and whole body were determined by standard methods (AOAC, 2005). Moisture was determined by oven-drying at $105^{\circ} \mathrm{C}$ until constant weight. Crude protein $(\mathrm{N} \times 6.25)$ was determined by the Kjeldahl method after acid digestion using a semi-automated Kjeldahl System (FOSS Kjeltec 2300). Crude lipid was determined by the ether-extraction method using a Soxhlet System (FOSS Soxtec2043). Ash content was determined by incinerating the sample in muffle furnace at $550^{\circ} \mathrm{C}$ for $24 \mathrm{~h}$. Amino acids were analysed following acid hydrolysis using high-pressure liquid chromatography (HPLC; Waters, USA) (Table 2).
Table 2

Amino acid profile of the diets.

\begin{tabular}{ll}
\hline Amino acid profile & Analysed amino acids of the diets (\% dry diet) \\
\hline EAAs & \\
Valine & 1.36 \\
Isoleucine & 1.64 \\
Leucine & 1.75 \\
Threonine & 1.83 \\
Tryptophan & 1.07 \\
Phenylalanine & 1.84 \\
Methionine & 1.62 \\
Lysine & Variable \\
Arginine & 1.96 \\
Histidine & 1.47 \\
& \\
NEAAs & \\
Aspartic acid & 1.45 \\
Glutamic acid & 1.45 \\
Serine & 0.95 \\
Glycine & Variable \\
Alanine & 1.13 \\
Proline & 10.79 \\
Cysteine & 1.06 \\
Tyrosine & 1.91 \\
\hline
\end{tabular}

\subsection{Hematobiochemical analyses}

The erythrocyte (RBC) count was done using a Neubauer counting chamber after diluting the blood (1:200) using an isotonic erythrocyte dilution solution. The total proteins, glucose, triglycerides and creatinine in the serum were analysed using commercial diagnostic kits (Tulip diagnostics Ltd., Goa, India). The erythrocyte count was determined using the formula: Number of RBC (millions/ $\mathrm{mm}^{3}$ ) $=$ (number of counted $\mathrm{RBC} \times$ dilution)/ (number of counted squares $\times$ volume of square)

\subsection{Statistical analysis}

Data were subjected to one-way ANOVA as a preliminary way to assess the significance among the treatments. It was observed that the treatment effects were significant for the variables final weight, FCR, PER, SGR, HSI, VSI, WG\%, IPFR, whole body protein and lipid, total serum proteins and RBC count except for whole body moisture, ash, serum glucose, triglycerides and creatinine. Further, a contrast analysis was performed by taking both linear and quadratic orthogonal polynomials and significance was seen for most of the responses indicating the relevance of a second order model for assessing the relationship among the response and levels of lysine in diet. Hence, a second order model of the following form was fitted:

$f\left(x_{u}\right)=\beta_{0}+\beta_{1} x_{u}+\beta_{2} x_{u}^{2}+e_{u}$

where $u=1,2, \ldots, N, x_{u}$ is the level of the lysine in diet in the $u^{\text {th }}$ treatment, $f\left(x_{u}\right)$ denotes the response obtained from $\mathrm{u}^{\text {th }}$ treatment and $e_{u}$ is the random error associated with the uth observation that is independently and normally distributed with mean zero and common variance $\sigma^{2}, \beta_{0}$ is the intercept, $\beta_{1}$ is the linear regression coefficient and $\beta_{2}$ is the quadratic regression coefficient. Adequacy of the fitted model was assessed by $\mathrm{R}^{2}$, coefficient of determination and its statistical significance was tested by F-test. All statistical analyses were performed using the SAS 9.4 (SAS Institute Inc.) software for Windows (SAS, 2013).

\section{Results}

The responses of the silver pompano juveniles to the increasing levels of lysine in the diets are summarized in Tables 3, 4. No external pathological signs were observed in the fish during the course of the experiment. Poor growth and low feed utilization were observed in fish 
Table 3

Growth performance, feed utilization and body condition indices of silver pompano fed diets containing graded lysine levels.

\begin{tabular}{|c|c|c|c|c|c|c|}
\hline & \multicolumn{6}{|c|}{ Dietary lysine levels } \\
\hline & 1.52 & 1.85 & 2.21 & 2.49 & 2.74 & 2.98 \\
\hline Average initial weight (g) & $6.33 \pm 0.17$ & $6.23 \pm 0.16$ & $6.27 \pm 0.01$ & $6.31 \pm 0.01$ & $6.26 \pm 0.02$ & $6.25 \pm 0.02$ \\
\hline Average final weight $(\mathrm{g})$ & $13.35 \pm 0.24$ & $17.21 \pm 0.16$ & $19.71 \pm 0.12$ & $18.68 \pm 0.19$ & $18.42 \pm 0.31$ & $17.15 \pm 0.45$ \\
\hline Weight gain (\%) & $110.82 \pm 3.59$ & $176.12 \pm 2.58$ & $214.17 \pm 1.77$ & $196.06 \pm 3.94$ & $194.27 \pm 5.73$ & $174.44 \pm 7.90$ \\
\hline Specific growth rate & $0.89 \pm 0.02$ & $1.21 \pm 0.01$ & $1.36 \pm 0.01$ & $1.29 \pm 0.02$ & $1.28 \pm 0.02$ & $1.20 \pm 0.03$ \\
\hline Feed conversion ratio & $3.58 \pm 0.12$ & $2.26 \pm 0.03$ & $1.91 \pm 0.02$ & $2.12 \pm 0.03$ & $2.12 \pm 0.05$ & $2.24 \pm 0.09$ \\
\hline Protein efficiency ratio & $0.70 \pm 0.02$ & $1.11 \pm 0.02$ & $1.31 \pm 0.01$ & $1.18 \pm 0.02$ & $1.18 \pm 0.03$ & $1.12 \pm 0.05$ \\
\hline Hepato- somatic index & $1.34 \pm 0.03$ & $1.06 \pm 0.01$ & $0.98 \pm 0.02$ & $0.99 \pm 0.01$ & $1.01 \pm 0.01$ & $1.08 \pm 0.04$ \\
\hline Viscerosomatic index & $9.93 \pm 0.47$ & $8.95 \pm 0.11$ & $8.67 \pm 0.74$ & $8.09 \pm 0.62$ & $8.54 \pm 0.47$ & $10.11 \pm 0.19$ \\
\hline Intra peritoneal fat ratio (IPFR) & $11.65 \pm 0.21$ & $10.03 \pm 0.06$ & $9.47 \pm 0.21$ & $9.09 \pm 0.51$ & $9.50 \pm 0.59$ & $8.69 \pm 0.24$ \\
\hline Survival (\%) & 95.83 & 95.85 & 100 & 95.83 & 100 & 95.83 \\
\hline
\end{tabular}

Means were obtained from triplicates and expressed as Mean \pm SE.

fed low levels of dietary lysine.

The responses such as final weight, FCR, PER, SGR, HSI, VSI, WG\%, IPFR, whole body protein and lipid, total serum proteins and RBC count were significantly affected due to dietary lysine. On the other hand, no significant differences were observed among different treatments with respect to whole body moisture, ash, serum glucose, triglycerides and creatinine. The statistical significance of the estimated parameters and the model fitness are given in Tables 5, 6 .

The WG\% of fish in different treatments ranged from 110.82 to $196.06 \%$, and showed an optimum at $2.40 \%$ of dietary lysine (Fig. 1). The best fit equation demonstrating the relationship of WG\% $\left(f\left(x_{u}\right)\right)$ with dietary lysine $\left(x_{u}\right)$ can be represented as:

$f\left(x_{u}\right)=-490.07+581.18 x_{u}-120.71 x_{u}^{2}$

The SGR of fish in different treatments ranged from 0.89 to 1.36 , and showed an optimum at $2.42 \%$ of dietary lysine (Fig. 2). The best fit equation demonstrating the relationship of SGR $\left(f\left(x_{w}\right)\right)$ with dietary lysine $\left(x_{u}\right)$ can be represented as:

$f\left(x_{u}\right)=-1.86+2.66 x_{u}-0.55 x_{u}^{2}$

The FCR of fish in different treatments ranged from 1.91 to 3.58 , with an optimum value obtained at $2.45 \%$ of dietary lysine (Fig. 3 ). The best fit equation demonstrating the relationship of FCR $\left(f\left(x_{w}\right)\right)$ with dietary lysine $\left(x_{u}\right)$ can be represented as:

$f\left(x_{u}\right)=12.63-8.77 x_{u}+1.79 x_{u}^{2}$

The PER of fish in different treatments ranged from 0.70 to 1.18 and showed an optimum at $2.42 \%$ of dietary lysine (Fig. 4). The best fit equation demonstrating the relationship of PER $\left(f\left(x_{u}\right)\right)$ with dietary lysine $\left(x_{u}\right)$ can be represented as:

$f\left(x_{u}\right)=-2.59+3.18 x_{u}-0.65 x_{u}^{2}$

Based on the above equations of second order model, the best WG\%,
SGR, FCR and PER were evident at lysine levels of $2.40 \%, 2.42 \%$, $2.45 \%$ and $2.42 \%$ of the diet, respectively (Figs. 1-4). Hence it can be concluded that the optimum dietary lysine level required for $T$. blochii lies in the range of $2.40-2.45 \%$ of dry diet $(5.71-5.83 \mathrm{~g} / 100 \mathrm{~g}$ of dietary protein).

\section{Discussion}

Results of this study indicated that dietary lysine requirement of juvenile silver pompano is between $2.42 \%$ dry diet $(5.76 \%$ of dietary protein) and $2.40 \%$ dry diet (5.71\% of dietary protein) when estimated by quadratic regression analysis on SGR\% and WG\%, respectively. The lysine requirement for juvenile silver pompano in this study $(5.71-5.83 \%$ of dietary protein) is similar to that of Japanese seabass (5.80\%) (Mai et al., 2006), carp (5.7\%) (Nose, 1979), red drum (5.7\%) (Brown et al., 1988), African Catfish (5.7\%) (Fagbenro et al., 1998), yellow croaker (5.7\%) (Zhang et al., 2008) and for rohu juveniles (5.6\%) (Murthy and Varghese, 1997); but is higher than those reported for rainbow trout (3.7\%) (Kim et al., 1992), coho salmon (3.8\%) (Arai and Ogata, 1991), Nile tilapia fingerlings (5.1\%) (Santiago and Lovell, 1988), cobia juveniles (5.4\%) (Zhou et al., 2007), Chinese sucker (5.5\%) (Lin et al., 2013) or stinging catfish (5.3\%) (Farhat and Khan, 2013) and lower than that for golden pompano (Trachinotus ovatus) (6.7\%) (Du et al., 2011), catla (6.2\%) (Ravi and Devaraj, 1991), or silver perch (6.0\%) (Yang et al., 2011). The wide variation observed in the requirements for lysine among fish species may be due to the differences in dietary protein sources, the reference protein used to simulate the amino acid pattern (Forster and Ogata, 1998), diet formulation, size and age of fish, genetic and species differences, feeding practices and rearing conditions (Ruchimat et al., 1997). Generally, higher lysine requirement is reported for fish that have high dietary protein requirements (marine fish and freshwater carnivorous fish) as compared to those that have low protein requirements (omnivorous and

Table 4

Serum biochemical parameters, RBC count and proximate composition of silver pompano fed diets containing graded levels of lysine.

\begin{tabular}{|c|c|c|c|c|c|c|}
\hline & \multicolumn{6}{|c|}{ Dietary lysine levels } \\
\hline & 1.52 & 1.85 & 2.21 & 2.49 & 2.74 & 2.98 \\
\hline Total serum protein $(\mathrm{mg} / \mathrm{dL})$ & $3.09 \pm 0.03$ & $3.39 \pm 0.13$ & $4.73 \pm 0.11$ & $4.95 \pm 0.04$ & $5.34 \pm 0.23$ & $5.18 \pm 0.18$ \\
\hline Serum glucose (mg/dL) & $146.67 \pm 8.19$ & $147.66 \pm 5.89$ & $151.66 \pm 2.33$ & $146.00 \pm 2.33$ & $147.33 \pm 3.38$ & $152.66 \pm 1.76$ \\
\hline Serum triglycerides $(\mathrm{mg} / \mathrm{dL})$ & $181.6 \pm 5.04$ & $174.7 \pm 3.48$ & $175.0 \pm 4.72$ & $183.0 \pm 3.05$ & $181.67 \pm 6.36$ & $183.34 \pm 4.18$ \\
\hline Creatinine (mg/dL) & $1.36 \pm 0.10$ & $1.39 \pm 0.03$ & $1.33 \pm 0.04$ & $1.35 \pm 0.09$ & $1.39 \pm 0.08$ & $1.37 \pm 0.01$ \\
\hline Red Blood Cell count $\left(\times 10^{9} / \mathrm{ml}\right)$ & $7.60 \pm 0.17$ & $8.07 \pm 0.15$ & $9.77 \pm 0.18$ & $9.86 \pm 0.20$ & $10.33 \pm 0.37$ & $10.20 \pm 0.15$ \\
\hline Moisture(\%) & $67.33 \pm 0.49$ & $67.58 \pm 0.08$ & $68.1 \pm 0.41$ & $68.23 \pm 0.18$ & $68.57 \pm 0.63$ & $68.92 \pm 0.28$ \\
\hline Crude protein (\%) & $17.2 \pm 0.21$ & $18.23 \pm 0.20$ & $18.5 \pm 0.23$ & $19.4 \pm 0.12$ & $19.6 \pm 0.15$ & $19.77 \pm 0.33$ \\
\hline Crude fat(\%) & $11.10 \pm 0.12$ & $10.63 \pm 0.09$ & $10.10 \pm 0.25$ & $9.57 \pm 0.12$ & $9.53 \pm 0.17$ & $9.73 \pm 0.09$ \\
\hline Ash (\%) & $4.64 \pm 0.19$ & $4.58 \pm 0.09$ & $4.40 \pm 0.07$ & $4.48 \pm 0.18$ & $4.36 \pm 0.11$ & $4.49 \pm 0.16$ \\
\hline
\end{tabular}

Means were obtained from triplicates and expressed as Mean \pm SE. 
Table 5

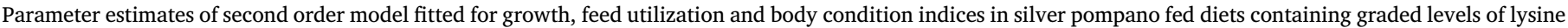
along with optimum value obtained by canonical analysis.

\begin{tabular}{|c|c|c|c|c|c|c|c|c|}
\hline & \multicolumn{8}{|l|}{ Responses } \\
\hline & Final weight (g) & WG (\%) & SGR & FCR & PER & HSI & VSI & IPFR \\
\hline$\beta_{0}$ & $\begin{array}{l}-24.21^{* *} \\
(3.25)\end{array}$ & $\begin{array}{l}-490.07^{* *} \\
(58.37)\end{array}$ & $\begin{array}{l}-1.86^{* *} \\
(0.27)\end{array}$ & $\begin{array}{l}12.63^{* * *} \\
(1.19)\end{array}$ & $\begin{array}{l}-2.59^{* *} \\
(0.41)\end{array}$ & $\begin{array}{l}3.54^{* *} \\
(0.25)\end{array}$ & $\begin{array}{l}24.52^{* *} \\
(3.04)\end{array}$ & $\begin{array}{l}20.83^{* *} \\
(3.50)\end{array}$ \\
\hline$\beta_{1}$ & $\begin{array}{l}36.28^{* *} \\
(2.99)\end{array}$ & $\begin{array}{l}581.18^{* *} \\
(53.79)\end{array}$ & $\begin{array}{l}2.66^{* *} \\
(0.24)\end{array}$ & $\begin{array}{l}-8.77^{\text {*** }} \\
(1.10)\end{array}$ & $\begin{array}{l}3.18^{* * *} \\
(0.38)\end{array}$ & $\begin{array}{l}-2.14 \\
(0.23)\end{array}$ & $\begin{array}{l}-14.27^{\text {*** }} \\
(2.80)\end{array}$ & $\begin{array}{l}-8.45 \\
(3.23)\end{array}$ \\
\hline$\beta_{2}$ & $\begin{array}{l}-7.54^{* *} \\
(0.66)\end{array}$ & $\begin{array}{l}-120.71^{\text {*** }} \\
(11.91)\end{array}$ & $\begin{array}{l}-0.55^{* *} \\
(0.05)\end{array}$ & $\begin{array}{l}1.79^{* *} \\
(0.24)\end{array}$ & $\begin{array}{l}-0.65^{* *} \\
(0.08)\end{array}$ & $\begin{array}{l}0.44^{* *} \\
(0.05)\end{array}$ & $\begin{array}{l}3.13^{* *} \\
(0.62)\end{array}$ & $\begin{array}{l}1.51 \\
(0.71)\end{array}$ \\
\hline $\mathrm{R}^{2}$ & $0.93^{* *}$ & $0.91^{* * *}$ & $0.92 * *$ & $0.87^{* *}$ & $0.87^{* * *}$ & $0.89^{* *}$ & $0.63^{* *}$ & $0.70^{* *}$ \\
\hline Optimum dietary lysine & 2.40 & 2.40 & 2.42 & 2.45 & 2.42 & 2.41 & 2.27 & 2.80 \\
\hline Response at optimum lysine & 19.41 & 209.48 & 1.35 & 1.88 & 1.27 & 0.95 & 8.26 & 8.97 \\
\hline
\end{tabular}

Values in parentheses indicate SE of estimates.

** Significance at $\mathrm{P}<.01$.

herbivorous fish) (Zhou et al., 2007).

In the present study, there was a marked decline in growth response and diet utilization below the optimum requirement level for lysine. Fish fed lysine deficient diets (D1 and D2) showed reduced WG, SGR and PER, while growth response and diet utilization were improved with supplementation of crystalline L-lysine. The results indicate that lysine is essential for the optimum growth of juvenile silver pompano. The fish fed high dietary lysine of $2.49 \%$ to $2.98 \%$ (diets 4,5 and 6) showed slightly lower SGR as compared to the optimum dietary lysine level. Besides, fish fed lower dietary lysine showed significantly lower WG, SGR and PER compared to the optimum dietary lysine level. Reduced growth performance and loss of appetite are reported due to dietary lysine deficiency in several fish species such as milkfish (Borlongan and Benitez, 1990), Indian major carp (Khan and Jafri, 1993; Murthy and Varghese, 1997; Ahmed and Khan, 2004) and Japanese sea bass (Mai et al., 2006). Fish fed high dietary lysine than the optimum level did not improve growth and feed utilization compared to the optimum dietary lysine level. These results are similar to those reported for red sea bream (Forster and Ogata, 1998), yellowtail (Ruchimat et al., 1997), Japanese sea bass (Mai et al., 2006) and grouper (Luo et al., 2006). Reduced growth and feed utilization due to higher dietary lysine was reported in rainbow trout (Walton et al., 1984); rohu (Murthy and Varghese, 1997); mrigal (Ahmed and Khan, 2004).

In the present study, HSI and VSI were significantly affected by

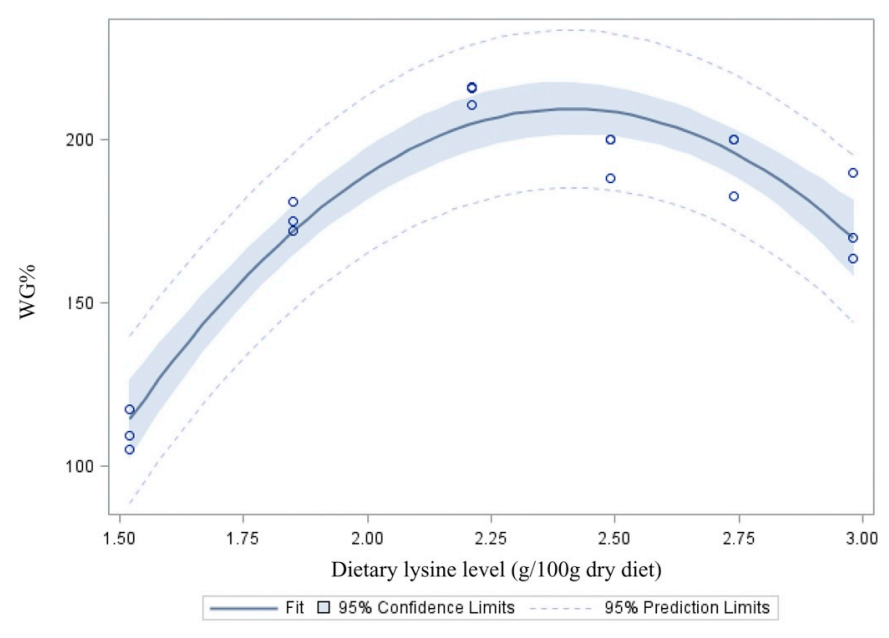

Fig. 1. Relationship of WG\% with dietary lysine levels.

dietary lysine level, which was in agreement with other studies in cobia (Zhou et al., 2007), turbot (Peres and Oliva-Teles, 2008) and pacu (Bicudo et al., 2009) which reported that those fish fed low lysine tended to have higher IPFR, HSI and VSI than those fed high lysine diets. However, Walton et al., 1984 reported no significant difference in HSI in rainbow trout fed different levels of lysine. However, Luo et al.

Table 6

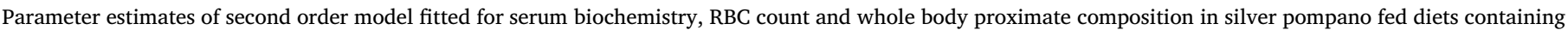
graded levels of lysine along with optimum value obtained by canonical analysis.

\begin{tabular}{|c|c|c|c|c|c|c|c|c|c|}
\hline & \multicolumn{9}{|l|}{ Responses } \\
\hline & \multirow{2}{*}{$\begin{array}{l}\text { Total serum } \\
\text { protein }(\mathrm{mg} / \mathrm{dL})\end{array}$} & \multirow{2}{*}{$\begin{array}{l}\text { Serum glucose } \\
(\mathrm{mg} / \mathrm{dL})\end{array}$} & \multirow{2}{*}{$\begin{array}{l}\text { Serum triglycerides } \\
(\mathrm{mg} / \mathrm{dL})\end{array}$} & \multirow{2}{*}{$\begin{array}{l}\text { Creatinine (mg/ } \\
\text { dL) }\end{array}$} & \multirow{2}{*}{$\begin{array}{l}\text { RBC count } \\
\left(\times 10^{9} / \mathrm{ml}\right)\end{array}$} & \multicolumn{4}{|c|}{ Whole body composition } \\
\hline & & & & & & Moisture, \% & $\begin{array}{l}\text { Crude } \\
\text { protein, \% }\end{array}$ & $\begin{array}{l}\text { Crude fat, } \\
\%\end{array}$ & Ash, \% \\
\hline$\beta_{0}$ & $\begin{array}{l}-3.81 \\
(1.77)\end{array}$ & $\begin{array}{l}149.22^{* *} \\
(47.09)\end{array}$ & $\begin{array}{l}218.26 \\
(41.79)\end{array}$ & $\begin{array}{l}1.52 \\
(0.60)\end{array}$ & $\begin{array}{l}-1.35 \\
(2.39)\end{array}$ & $\begin{array}{l}66.56^{* *} \\
(2.85)\end{array}$ & $\begin{array}{l}11.77^{* * *} \\
(1.72)\end{array}$ & $\begin{array}{l}16.75^{* *} \\
(1.47)\end{array}$ & $\begin{array}{l}5.89^{* *} \\
(1.26)\end{array}$ \\
\hline$\beta_{1}$ & $\begin{array}{l}5.83^{* *} \\
(1.63)\end{array}$ & $\begin{array}{l}-3.09 \\
(43.40)\end{array}$ & $\begin{array}{l}-39.85 \\
(38.51)\end{array}$ & $\begin{array}{l}-0.15 \\
(0.55)\end{array}$ & $\begin{array}{l}7.69^{* *} \\
(2.21)\end{array}$ & $\begin{array}{l}0.22 \\
(2.63)\end{array}$ & $\begin{array}{l}4.54 \\
(1.59)\end{array}$ & $\begin{array}{l}-4.99 \\
(1.35)\end{array}$ & $\begin{array}{l}-1.15 \\
(1.16)\end{array}$ \\
\hline$\beta_{2}$ & $\begin{array}{l}-0.93^{* *} \\
(0.36)\end{array}$ & $\begin{array}{l}1.20 \\
(9.61)\end{array}$ & $\begin{array}{l}9.61 \\
(8.53)\end{array}$ & $\begin{array}{l}0.03 \\
(0.12)\end{array}$ & $\begin{array}{l}-1.26 \\
(0.49)\end{array}$ & $\begin{array}{l}0.19 \\
(0.58)\end{array}$ & $\begin{array}{l}-0362 \\
(0.35)\end{array}$ & $\begin{array}{l}0.87 \\
(0.30)\end{array}$ & $\begin{array}{l}0.22 \\
(0.26)\end{array}$ \\
\hline $\mathrm{R}^{2}$ & $0.89^{* *}$ & 0.02 & 0.13 & 0.0049 & $0.87^{* * *}$ & 0.56 & $0.91^{* *}$ & $0.84^{* *}$ & 0.14 \\
\hline $\begin{array}{l}\text { Optimum dietary } \\
\text { lysine }\end{array}$ & 3.13 & 1.28 & 2.07 & 2.23 & 3.03 & \# & 3.66 & 2.86 & 2.57 \\
\hline $\begin{array}{l}\text { Response at optimum } \\
\text { lysine }\end{array}$ & 5.33 & 147.24 & 176.97 & 1.36 & 10.31 & \# & 20.09 & 9.61 & 4.42 \\
\hline
\end{tabular}

Values in parentheses indicate SE of estimates.

\# A logical optimum does not exist.

** Significance at $P<.01$. 


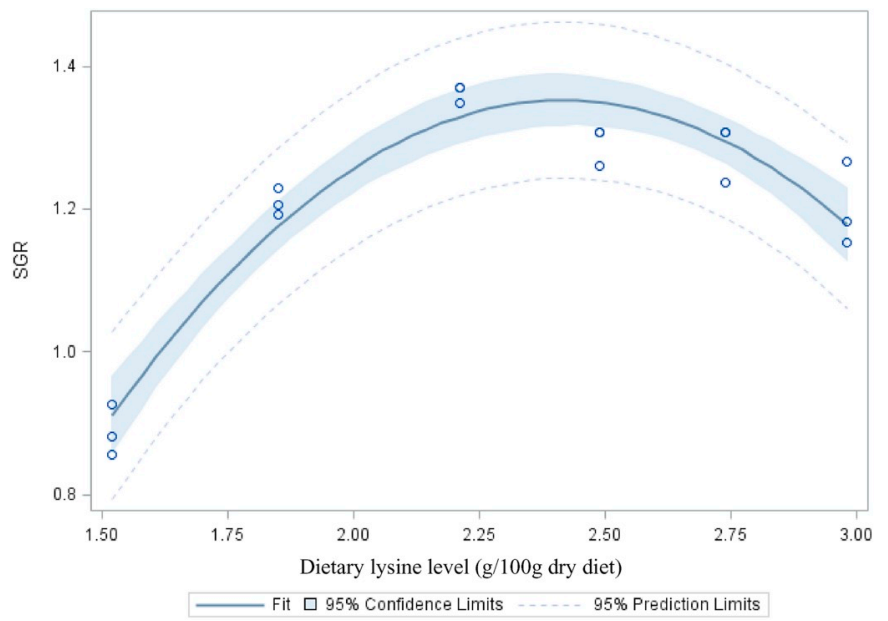

Fig. 2. Relationship of SGR with dietary lysine levels.

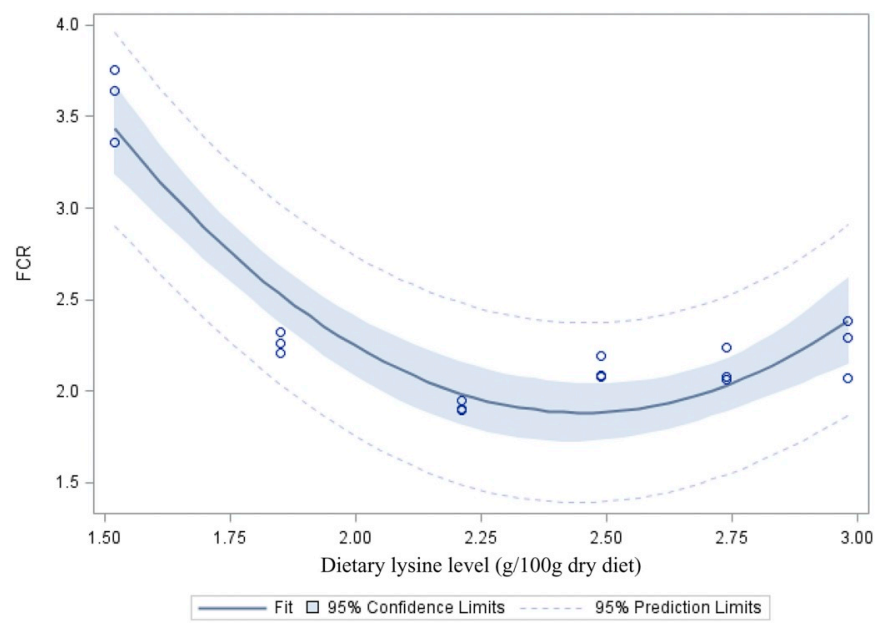

Fig. 3. Relationship of FCR with dietary lysine levels.

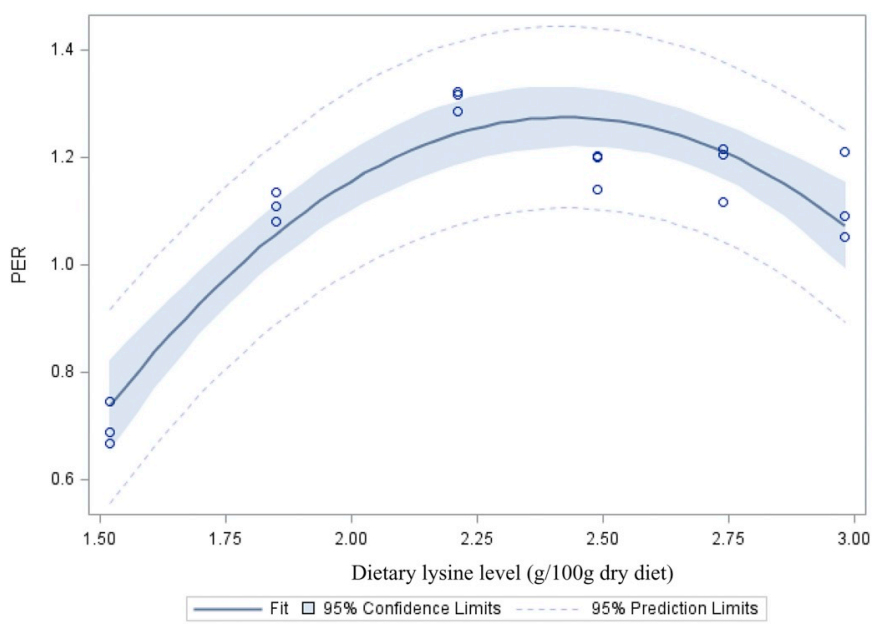

Fig. 4. Relationship of PER with dietary lysine levels.

(2006) reported that grouper fed low lysine diets tended to have lower HSI than those fed high lysine diets. IPFR and body lipid was significantly higher in the fish of D1 group, and a decreasing trend of IPFR and body lipid was observed with increase in dietary lysine levels. This was in accord with Yang et al., 2011 in grass carp and contradicts the reports in red seabream and freshwater catfish (Chatzifotis et al., 1996;
Tantikitti and Chimsung, 2001), respectively who reported lower body lipid content and IPFR in the groups not supplemented with lysine.

An increase in body protein and decrease in body lipid was observed with an increase in dietary lysine levels. Lysine plays an important role in the synthesis of carnitine (Walton et al., 1984), which has a substantial function in the transport of long-chain fatty acids from the cytoplasm into the mitochondria for $\beta$-oxidation ( $\mathrm{Wu}, 2013)$. Thus, fish fed diets deficient in lysine showed increased body lipid deposition as observed in several fish species such as yellow tail (Ruchimat et al., 1997), rainbow trout (Walton et al., 1984), large yellow croaker (Xie et al., 2012), black sea bream (Zhou et al., 2010), silver perch (Yang et al., 2011) and Atlantic salmon (Helland et al., 2011). However, an increase in body lipid due to lower dietary lysine levels was not observed in the freshwater fish, mrigal (Ahmed and Khan, 2004). Thus, our results of reduction in carcass lipids due to lysine supplementation may be specific to marine fishes.

The anti-anaemic property of lysine is well documented by several studies in rats (Hogan et al., 1941; Tanphaichitr et al., 1971). There was a significant difference in the erythrocyte count of fishes among the treatments in our study, with a significantly lower count in the treatments with lower levels of dietary lysine (Diets 1 and 2), while in higher dietary levels of lysine, a higher count was observed. The erythrocyte count was reported to be lower in different fish species fed lysine deficient diets (Yang et al., 2011; Ruchimat et al., 1997; Bicudo et al., 2009), which are in agreement with our study. On the other hand, Zhou et al. (2007) and Ruchimat et al. (1997) observed no effect of dietary lysine on red blood cell count in the juveniles of cobia and yellow tail, respectively. However, our result indicated a positive effect of lysine on the red blood cell count.

Vegetable protein ingredients have replaced a considerable amount of fishmeal in fish feeds over the years. In order to balance the deficiency of essential amino acids in plant protein sources, crystalline amino acids should be supplied to meet the dietary amino acid requirement and favour amino acid anabolism for protein synthesis and muscle growth. In the present study, based on quadratic regression analysis, the lysine requirement of silver pompano was estimated in the range of $2.40-2.45 \%$ of dry diet (5.71-5.83\% of dietary crude protein). The data generated on the quantitative dietary lysine requirement of silver pompano juveniles would be useful in developing lysine balanced low cost practical diets for the grow out culture of this candidate species.

\section{Declarations of interest}

None.

\section{Acknowledgements}

The authors are grateful to the Director, ICAR-Central Marine Fisheries Research Institute, Kochi and the Director, ICAR-Central Institute of Fisheries Education, Mumbai, India for providing the necessary facilities to carry out the study. The wet lab support extended by Mr. B. Vishnu is acknowledged. Funding support for this work came from the Indian Council of Agricultural Research, New Delhi, India, which is duly acknowledged.

\section{References}

Abidi, S.F., Khan, M.A., 2007. Dietary leucine requirement of fingerling Indian major carp, Labeo rohita (Hamilton). Aquac. Res. 38, 478-486. https://doi.org/10.1111/j. 1365-2109.2007.01687.x.

Ahmed, I., Khan, M.A., 2004. Dietary lysine requirement of fingerling Indian major carp, Cirrhinus mrigala (Hamilton). Aquaculture 235, 499-511. https://doi.org/10.1016/j. aquaculture.2003.12.009.

Akiyama, T., Arai, S., Murai, T., Nose, T., 1985. Threonine, histidine and lysine requirements of chum salmon fry. Nippon Suisan Gakkaishi 51, 635-639. https://doi. org $/ 10.2331$ /suisan.51.635.

AOAC (Ed.), 2005. Official Methods of Analysis of AOAC International, 18th ed. AOAC 
International, Gaithersburg, Md.

Arai, S., Ogata, H., 1991. Quantitative amino acid requirements of fingerling coho salmon. In: Collie, M.R., McVey, J.P. (Eds.), Proceedings of the Twentieth US-Japan Symposium on Aquaculture Nutrition. UJNR Department of Commerce, Newport, OR, USA, pp. 19-28.

Berge, G.E., Sveier, H., Lied, E., 1998. Nutrition of Atlantic salmon (Salmo salar); the requirement and metabolic effect of lysine. Comp. Biochem. Physiol. 120A, 477-485. https://doi.org/10.1016/S1095-6433(98)10049-1.

Bicudo, A.J.A., Sado, R.Y., Cyrino, J.E.P., 2009. Dietary lysine requirement of juvenile pacu Piaractus mesopotamicus (Holmberg, 1887). Aquaculture 297, 151-156. https:// doi.org/10.1016/j.aquaculture.2009.09.031.

Borlongan, I.G., Benitez, L.V., 1990. Quantitative lysine requirement of milkfish (Chanos chanos) juveniles. Aquaculture 87, 341-347. https://doi.org/10.1016/00448486(90)90071-T.

Brown, P.B., Davis, D.A., Robinson, E.H., 1988. An estimate of the dietary lysine requirement of juvenile red drum, Sciaenops ocellatus. J. World Aquac. Soc. 19, 109-112. https://doi.org/10.1111/j.1749-7345.1988.tb01053.x.

Cao, J.M., Chen, Y., Zhu, X., Huang, Y.H., Zhao, H.X., Li, G.L., Lan, H.B., Chen, B., Pan, Q., 2012. A study on dietary L-lysine requirement of juvenile yellow catfish Pelteobagrus fulvidraco. Aquac. Nutr. 18, 35-45. https://doi.org/10.1111/j.1365-2095.2011. 00874.x.

Chatzifotis, S., Takeuchi, T., Seikai, T., 1996. The effect of dietary carnitine supplementation on growth of red sea bream (Pagrus major) fingerlings at two levels of dietary lysine. Aquaculture 147, 235-248. https://doi.org/10.1016/S0044-8486(96) 01403-2.

Du, Q., Lin, H.Z., Niu, J., Ding, X., Huang, Z., Chen, X., Chen, Y.F., 2011. Dietary lysine requirements of juvenile pompano (Trachinotus ovatus). Chin. J. Anim. Nutr. 23, $1725-1732$.

Fagbenro, O.A., Balogun, A.M., Bello-Olusoji, O.A., Fasakin, E.A., 1998. Dietary lysine requirement of the African catfish, Clarias gariepinus. J. Appl. Aquac. 8, 71-77. https://doi.org/10.1300/J028v08n02_07.

Farhat, D., Khan, M.A., 2013. Dietary L-lysine requirement of fingerling stinging catfish, Heteropneustes fossilis (Bloch) for optimizing growth, feed conversion, protein and lysine deposition. Aquac. Res. 44, 523-533. https://doi.org/10.1111/j.1365-2109. 2011.03054.x.

Forster, I., Ogata, H.Y., 1998. Lysine requirement of juvenile Japanese flounder Paralichthys olivaceus and juvenile red sea bream Pagrus major. Aquaculture 161, 131-142. https://doi.org/10.1016/S0044-8486(97)00263-9.

Fournier, V., Gouillou-Coustans, M.F., Metailler, R., Vachot, C., Moriceau, J., Le Delliou, H., Huelvan, C., Desbruyeres, E., Kaushik, S.J., 2003. Excess dietary arginine affects urea excretion but does not improve $\mathrm{N}$ utilization in rainbow trout Oncorhynchus mykiss and turbot Psetta maxima. Aquaculture 217, 559-576. https://doi.org/10. 1016/S0044-8486(02)00420-9.

Gatlin, D.M., Barrows, F.T., Brown, P., Dabrowski, K., Gaylord, T.G., Hardy, R.W. Herman, E., Hu, G.S., Krogdahl, A., Nelson, R., Overturf, K., Rust, M., Sealey, W., Skonberg, D., Souza, E.J., Stone, D., Wilson, R., Wurtele, E., 2007. Expanding the utilization of sustainable plant products in aquafeeds: a review. Aquac. Res. 38, 551-579. https://doi.org/10.1111/j.1365-2109.2007.01704.x.

Gopakumar, G., Abdul Nazar, A.K., Jayakumar, R., Tamilmani, G., Sakthivel, M., Kalidas, C., Kumar, P.Ramesh, Rao, Hanumantha, Premjothi, R., Balamurugan, V., Ramkumar, B., Jayasingh, M., Syda Rao, G., 2012. Broodstock development through regulation of photoperiod and controlled breeding of silver pompano, Trachinotus blochii (Lacepede, 1801) in India. Ind. J. Fish. 59 (1), 53-57.

Griffin, M.E., Brown, P.B., Grant, A.L., 1992. The dietary lysine requirement of juvenile hybrid striped bass. J. Nutr. 122, 1332-1337. https://doi.org/10.1093/jn/122.6. 1332.

Gurrea, M., Coloso, R.M., Borlongan, I.G., Serrano Jr., J.A., 2001. Lysine and arginine requirements of juvenile Asian sea bass (Lates calcarifer). J. Appl. Ichthyol. 17, 49-53.

Heilman, M.J., Spieler, R.E., 1999. The daily feeding rhythm to demand feeders and the effects of timed meal-feeding on the growth of juvenile Florida pompano, Trachinotus carolinus. Aquaculture 180, 53-64. https://doi.org/10.1016/S0044-8486(99) 00140-4.

Helland, G.B., Gatlin, D.M., Corrent, E., Helland, S.J., 2011. The minimum dietary lysine requirement, maintenance requirement and efficiency of lysine utilization for growth of Atlantic salmon smolts. Aquac. Res. 42, 1509-1529. https://doi.org/10.1111/j. 1365-2109.2010.02743.x.

Hogan, A.G., Powell, E.L., Guerrant, R.E., 1941. Anemia from lysine deficiency in deaminized casein. J. Biol. Chem. 137, 41.

Kapoor, D., R. Dayal and A.G. Ponniah, 2002. Fish biodiversity of India. National Bureau of Fish Genetic Resources Lucknow, India.775 p.

Ketola, H.G., 1983. Requirement for dietary lysine and arginine by fry of rainbow trout. J. Anim. Sci. 56, 101-107. https://doi.org/10.2527/jas1983.561101x.

Khan, M.A., Abidi, S.F., 2011. Effect of dietary L-lysine levels on growth, feed conversion, lysine retention efficiency and haematological indices of Heteropneustes fossilis(Bloch) fry. Aquac. Nutr. 17, e657-e667. https://doi.org/10.1111/j.1365-2095.2010. 00815.x

Khan, M.A., Jafri, A.K., 1993. Quantitative dietary requirement for some indispensable amino acids in the Indian major carp, Labeo rohita (Hamilton) fingerling. J. Aquac. Trop. 8, 67-80.

Kikuchi, K., Furuta, T., Honda, H., 1994. Utilization of soybean meal as a protein source in the diet of juvenile Japanese flounder, Paralichthys olivaceus. Suisan Zoshoku 42, 601-604. https://doi.org/10.11233/aquaculturesci1953.42.601.

Kim, K.I., Kayes, T.B., Amundson, C.H., 1992. Requirements for lysine and arginine by rainbow trout (Oncorhynchus mykiss). Aquaculture 106, 333-344. https://doi.org/10 1016/0044-8486(92)90265-M.

Li, P., Mai, K., Trushenski, J., Wu, G., 2009. New developments in fish amino acid nutrition: towards functional and environmentally oriented aquafeeds. Amino Acids 37, 43-53. https://doi.org/10.1007/s00726-008-0171-1.

Lin, Y., Gong, Y., Yuan, Y., Gong, S., Yu, D., Li, Q., Luo, Z., 2013. Dietary L-lysine requirement of juvenile Chinese sucker (Myxocyprinus asiaticus). Aquac. Res. 44, 1539-1549. https://doi.org/10.1111/j.1365-2109.2012.03161.x.

Luo, Z., Liu, Y.J., Mai, K.S., Tian, L.X., Tan, X.Y., Yang, H.J., Liang, G.Y., Liu, D.H., 2006 Quantitative L-lysine requirement of juvenile grouper Epinephelus coioides. Aquac. Nutr. 12, 165-172. https://doi.org/10.1111/j.1365-2095.2006.00392.x.

Mai, K.S., Zhang, L., Ai, Q.H., Duan, A.Y., Zhang, C.X., Li, H.T., Wan, J.L., Liufu, Z.G., 2006. Dietary lysine requirement of juvenile Japanese seabass, (Lateolabrax japonicus). Aquaculture 258, 535-542. https://doi.org/10.1016/j.aquaculture.2006.04 043.

Murthy, H.S., Varghese, T.J., 1997. Dietary requirements of juveniles of the Indian major carp, Labeo rohita, for the essential amino acid lysine. Isr. J. Aquac. Bamidgeh 49, $19-24$.

Nguyen, M.V., Ronnestad, I., Buttle, L., Lai, H.V., Espe, M., 2013. Imbalanced lysine to arginine ratios reduced performance in juvenile cobia (Rachycentron canadum) fed high plant protein diets. Aquac. Nutr. 20, 25-35. https://doi.org/10.1111/anu. 12043.

Nose, T., 1979. Summary report on the requirements of essential amino acids for carp. In: Halver, J.E., Tiews, K. (Eds.), Finfish Nutrition and Fish Diet Technology. Heinemann, Berlin, Germany, pp. 145-156.

Nose, T., Arai, S., Lee, D.L., Hashimoto, Y., 1974. A note on amino acids essential for growth of young carp. Bull. Jpn. Soc. Sci. Fish. 40, 903-908.

NRC (National Research Council), 1993. Nutrient Requirement of Fish. National Academy Press, Washington DC, USA.

NRC (National Research Council), 2011. Proteins and Amino Acids. Nutrient Requirements of Fish and Shrimp. National Academy Press, Washington, D.C., pp. 57-101.

Ogino, C., 1980. Requirements of carp and rainbow trout for essential amino acids. Nippon Suisan Gakkaishi 46, 171-174.

Peres, H., Oliva-Teles, A., 2008. Lysine requirement and efficiency of lysine utilization in turbot (Scophthalmus maximus) juveniles. Aquaculture 275, 283-290. https://doi. org /10.1016/j.aquaculture.2007.12.015.

Ravi, J., Devaraj, K.V., 1991. Quantitative essential amino acid requirements for growth of catla, Catla catla (Hamilton). Aquaculture 96, 281-291. https://doi.org/10.1016/ 0044-8486(91)90158-4.

Robinson, E.H., Wilson, R.P., Poe, W.E., 1980. Re-evaluation of the lysine requirement and lysine utilization by fingerling channel catfish. J. Nutr. 110, 2313-2316. https:// doi.org/10.1093/jn/110.11.2313.

Ruchimat, T., Masumoto, T., Hosokawa, H., Itoh, Y., Shimeno, S., 1997. Quantitative lysine requirement of yellowtail (Seriola quinqueradiata). Aquaculture 158, 331-339. https://doi.org/10.1016/S0044-8486(97)00215-9.

Santiago, C.B., Lovell, R.T., 1988. Amino acid requirements for growth of Nile tilapia. J. Nutr. 118, 1540-1546. https://doi.org/10.1093/jn/118.12.1540.

SAS 9.4 (SAS Institute Inc.), 2013. Product or service names are registered trademarks or trademarks of SAS Institute Inc. (Cary, NC, USA).

Small, B.C., Soares Jr., J.H., 2000. Quantitative dietary lysine requirement of juvenile striped bass Morone saxatilis. Aquacult. Nutr. 6, 207-212. https://doi.org/10.1046/j. 1365-2095.2000.00140.x.

Tanphaichitr, V., Horne, D.W., Broquist, H.P., 1971. Lysine, a precursor of carnitine in the rat. J. Biol. Chem. 246, 6364-6366.

Tantikitti, C., Chimsung, N., 2001. Dietary lysine requirement of freshwater catfish (Mystus nemurus Cuv. and Val.). Aquac. Res. 32, 135-141. https://doi.org/10.1046/ j.1355-557x.2001.00011.x.

Thoman, E.S., Davis, D.A., Arnold, C.R., 1999. Evaluation of grow out diets with varying protein and energy levels for red drum (Sciaenops ocellatus). Aquaculture 176, 343-353. https://doi.org/10.1016/S0044-8486(99)00118-0.

Valente, L.M.P., Moutou, K.A., Conceição, L.E.C., Engrola, S., Fernandes, J.M.O., Johnston, I.A., 2013. What determines growth potential and juvenile quality of farmed fish species? Rev. Aquacult. 5, S168-S193. https://doi.org/10.1111/raq 12020.

Walton, M.J., Cowey, C.B., Adron, J.W., 1984. The effect of dietary lysine levels on growth and metabolism of rainbow trout (Salmo gairdneri). Br. J. Nutr. 52, 115-122. https://doi.org/10.1079/BJN19840077.

Watanabe, W.O., 1995. Aquaculture of the Florida pompano and other jacks (Family Carangidae) in the Western Atlantic, Gulf of Mexico, and Caribbean basin: status and potential. In: Main, K.L., Rosenfeld, C. (Eds.), Culture of High-value Marine Fishes. Oceanic Institute, Honolulu, Hawaii, pp. 185-205.

Wilson, R.P., 2002. Amino acids and proteins. In: Halver, J.E., Hardy, R.W. (Eds.), Fish Nutrition, 3rd ed. Academic Press, San Diego, CA, pp. 144-175.

Wilson, R.P., Halver, J.E., 1986. Protein and amino acid requirements of fishes. Annu. Rev. Nutr. 6, 225-244. https://doi.org/10.1146/annurev.nu.06.070186.001301.

Wilson, R.P., Poe, W.E., 1985. Relationship of whole body and egg essential amino acid patterns to amino acid requirement patterns in channel catfish, Ictalurus punctatus. Comp. Biochem. Physiol. 80B, 385-388.

Wu, G., 2013. Amino Acids: Biochemistry and Nutrition. CRC Press, Boca Raton, Florida, USA.

Wu, G.Y., Bazer, F.W., Davis, T.A., Kim, S.W., Li, P., Rhoads, J.M., Satterfield, M.C., Smith, S.B., Spencer, T.E., Yin, Y.L., 2009. Arginine metabolism and nutrition in growth, health and disease. Amino Acids 37, 153-168. https://doi.org/10.1007/ s00726-008-0210-y.

Xie, F., Ai, Q., Mai, K., Xu, W., Wang, X., 2012. Dietary lysine requirement of large yellow croaker (Pseudosciaena crocea, Richardson 1846) larvae. Aquac. Res. 43, 917-928. https://doi.org/10.1111/j.1365-2109.2011.02906.x.

Yang, S.D., Liu, F.G., Liou, C.H., 2011. Assessment of dietary lysine requirement for silver 
perch (Bidyanus bidyanus) juveniles. Aquaculture 312, 102-108. https://doi.org/10. 1016/j.aquaculture.2010.12.011.

Zhang, C.X., Ai, Q.H., Mai, K.S., Tan, B.P., Li, H.T., Zhang, L., 2008. Dietary lysine requirement of large yellow croaker, Pseudosciaena crocea R. Aquaculture 283,

123-127. https://doi.org/10.1016/j.aquaculture.2008.06.035.

Zhou, Q.C., Wu, Z.H., Chi, S.Y., Yang, Q.H., 2007. Dietary lysine requirement of juvenile cobia (Rachycentron canadum). Aquaculture 273, 634-640. https://doi.org/10.1016/ j.aquaculture.2007.08.056.

Zhou, F., Shao, J., Xu, R., Ma, J., Xu, Z., 2010. Quantitative L-lysine requirement of juvenile black sea bream (Sparus macrocephalus). Aquac. Nutr. 16, 194-204. https:// doi.org/10.1111/j.1365-2095.2009.00651.x. 